\title{
ANALISIS VIDEO ANIMASI FILM PENDEK "MORIENDO" KARYA ANDREY PRATAMA
}

\author{
Yana Erlyana ${ }^{*}$ \\ ${ }^{1}$ Program Studi Desain Komunikasi Visual, Universitas Bunda Mulia, Jl. Lodan Raya No. 2 Ancol, \\ Jakarta Utara 14430, Indonesia
}

Diterima: 21 Febuari 2018/ Disetujui: 6 Maret 2018

\begin{abstract}
Animated short films have become popular in Indonesia, especially love story films. Whereas a lot of good stories can be made from different genres, these love story films could teach people more valuable lessons. Moriendo is an animated short film that socializes the local literature with a unique story and visual interest to provide refreshments to the audience. This short film is expected to be able to disseminate to the public about alternative literature that can be recognized locally and expands the genre of short animation in Indonesia. At this paper, author will analyze the content of the short movie from the perspective of visual communication design field.
\end{abstract}

Keyword: Moriendo, Animation, Short Movie, Death.

\begin{abstract}
ABSTRAK
Film animasi pendek sudah menjadi populer di Indonesia, terutama film kisah percintaan. Walaupun banyak cerita bagus dapat dibuat dari jenis tema cerita yang berbeda, film-film kisah percintaan ini dapat mengajarkan orang pelajaran berharga yang lebih banyak. Moreindo adalah film animasi pendek yang mensosialisasikan literatur lokal dengan cerita dan visual yang unik untuk memberikan sesuatu yang menyegarkan penonton. Film pendek ini diharapkan dapat menyebarkan kepada publik tentang literatur alternatif yang dapat dikenali secara lokal dan memperluas jenis tema film animasi pendek di Indonesia. Dalam penulisan ini, penulis akan menganalisis konten film pendek dari sudut pandang keilmuan Desain Komunikasi Visual.
\end{abstract}

Kata kunci: Moriendo, Animasi, Film pendek, Kematian

\section{PENDAHULUAN}

Insan-insan kreatif yang tergabung dalam industri kreatif saat ini sedang mendapat sorotan khusus sebagai salah satu industri yang berkembang cukup pesat di Indonesia dalam satu dekade terakhir. Salah satunya adalah industri penerbitan khususnya penerbitan karya sastra. Kini dapat ditemui berbagai jenis buku yang ditulis oleh insan-insan kreatif lokal. Namun masyarakat umumnya hanya mengetahui tulisan yang berbumbu percintaan, seperti novel ataupun teenlit. Padahal genre yang disuguhkan tidak hanya berbumbu percintaan saja, namun juga ada genre seperti fantasi, petualangan, misteri dan banyak lainnya. Novel-novel atau teenlit tersebut semakin dikenal masyarakat setelah banyaknya film layar lebar yang mengadaptasi cerita percintaan tersebut. Namun genre lain seakan kurang mendapat perhatian dari masyarakat padahal banyak sesuatu yang bisa didapat dari genre-genre tersebut.

Hal ini dapat dilihat dari beberapa permasalahan yang ada yaitu masih sedikitnya pengangkatan karya sastra yang matang dan memiliki cerita yang kuat ke dalam sebuah media komunikasi animasi, banyaknya tema-tema serupa dan monoton (umumnya percintaan, tragedi tentang anak yang tertukar) sebagai plot dalam tontonan yang tidak mendewasakan pandangan penonton, novel lokal yang disukai rata-rata bergenre percintaan dan teenlit, kurangnya minat pembaca membaca genre selain itu.

*email: yerlyana@bundamulia.ac.id 
Maka dari itu, Moriendo diciptakan guna mewujudkan animasi lokal yang menyuguhkan sesuatu yang baru, baik melalui tema, cerita, storytelling, gaya visual, yang berbeda dengan animasi lokal selama ini untuk penonton lebih dewasa dengan membawa pesan moral yang sublim. "Moriendo" karya Andrey Pratama adalah sebuah film pendek yang diadaptasi dari sebuah cerpen karangan Noviana Kusumawardhani yang berjudul "Sebuah Pagi dan Seorang Lelaki Mati", "Moriendo" bertutur mengenai perjumpaan seorang perempuan dengan seorang lelaki tua di sebuah taman. Setelah ditinggal pergi oleh seseorang yang dikasihinya, perempuan tersebut tidak lagi memiliki semangat untuk melanjutkan hidup, dan mengharap kematian akan segera menjemputnya. Si kakek tua yang ternyata jelmaan dari malaikat pencabut nyawa, menawarkan diri untuk mengambil jiwa dari perempuan tersebut, apabila diperkenankan. Lalu, apa yang terjadi di menit-menit berikutnya dalam "Moriendo" memiliki keterkaitan dengan upaya manusia untuk berdamai dengan kenangan-kenangan pahit di masa lampau, menerima jalan hidup yang dilalui dengan hati lapang terbuka, hingga pengorbanan.

Dalam penelitian ini akan menganalisi isi konten dari film animasi Moriendo dilihat dari teori yang berkaitan dengan perancangan sebuah film animasi pendek.

\section{METODE PENELITIAN}

Untuk dapat melakukan penelitian ini, maka digunakan metode penelitian kualitatif dengan pendekatan studi kasus secara deskriptif dimana penulis membahas lebih dalam mengenai sebuah program, kegiatan, aktivitas, proses, masalah dan lain-lain. Kasus-kasus ini dibatasi oleh waktu dan kegiatan, dimana peneliti menggunakan berbagai prosedur pengumpulan data.

Studi kasus ini akan mencermati bagaimana sebuah film animasi pendek animasi tercipta dengan menerapkan teoriteori yang terkait. Studi kasus yang peneliti gunakan hanya untuk satu objek yaitu film pendek Moriendo. Penelitian deskritif berfokus pada penjelasan sistematis tentang fakta yang diperoleh saat penelitian dilakukan.

\section{Prinsip Dasar Animasi}

Ada 12 prinsip yang harus dipenuhi untuk membuat sebuah animasi yang hidup;

\section{Solid Drawing}

Menggambar sebagai dasar utama animasi memegang peranan yang signifikan dalam menentukan baik proses maupun hasil, terutama animasi klasik. Seorang animator harus memiliki kepekaan terhadap anatomi, komposisi, berat, keseimbangan, pencahayaan, dsb. yang dapat dilatih melalui serangkaian observasi dan pengamatan, dimana dalam observasi itu salah satu yang harus dilakukan adalah: menggambar. Meskipun kini peran gambar yang dihasilkan sketsa manual sudah bisa digantikan oleh komputer, tetapi dengan pemahaman dasar dari prinsip menggambar akan menghasilkan animasi yang lebih peka.

\section{Timing \& Spacing}

Grim Natwick, seorang animator Disney pernah berkata, "Animasi adalah tentang timing dan spacing". Timing adalah tentang menentukan waktu kapan sebuah gerakan harus dilakukan, sementara spacing adalah tentang menentukan percepatan dan perlambatan dari bermacam-macam jenis gerak.

\section{Squash \& Stretch}

Squash and strecth adalah upaya penambahan efek lentur (plastis) pada objek atau figur sehingga seolah-olah memuai atau menyusut sehingga memberikan efek gerak yang lebih hidup. Penerapan squash and stretch pada figur atau benda hidup (misal: manusia, binatang, creatures) akan memberikan 'enhancement' sekaligus efek dinamis terhadap gerakan/ action tertentu, sementara pada benda mati (misal: gelas, meja, botol) penerapan squash and stretch akan membuat 
mereka (benda-benda mati tersebut) tampak atau berlaku seperti benda hidup.

\section{Anticipation}

Anticipation boleh juga dianggap sebagai persiapan/awalan gerak atau ancang-ancang. Seseorang yang bangkit dari duduk harus membungkukkan badannya terlebih dahulu sebelum benar-benar berdiri. Pada gerakan memukul, sebelum tangan maju harus ada gerakan mundur dulu. Dan sejenisnya.

\section{Slow In and Slow Out}

Sama seperti spacing yang berbicara tentang akselerasi dan deselerasi. Slow In dan Slow Out menegaskan kembali bahwa setiap gerakan memiliki percepatan dan perlambatan yang berbeda-beda. Slow in terjadi jika sebuah gerakan diawali secara lambat kemudian menjadi cepat. Slow out terjadi jika sebuah gerakan yang relatif cepat kemudian melambat.

6. Arcs

Dalam animasi, sistem pergerakan tubuh pada manusia, binatang, atau makhluk hidup lainnya bergerak mengikuti pola/jalur (maya) yang disebut Arcs. Hal ini memungkinkan mereka bergerak secara smooth dan lebih realistik, karena pergerakan mereka mengikuti suatu pola yang berbentuk lengkung (termasuk lingkaran, elips, atau parabola). Pola gerak semacam inilah yang tidak dimiliki oleh sistem pergerakan mekanik/ robotik yang cenderung patah-patah.

\section{Secondary Action}

Secondary action adalah gerakangerakan tambahan yang dimaksudkan untuk memperkuat gerakan utama supaya sebuah animasi tampak lebih realistik. Secondary action tidak dimaksudkan untuk menjadi 'pusat perhatian' sehingga mengaburkan atau mengalihkan perhatian dari gerakan utama. Kemunculannya lebih berfungsi memberikan emphasize untuk memperkuat gerakan utama.
8. Follow Through and Overlapping Action

Follow through adalah tentang bagian tubuh tertentu yang tetap bergerak meskipun seseorang telah berhenti bergerak. Misalnya, rambut yang tetap bergerak sesaat setelah berhenti berlari. Overlapping action secara mudah bisa dianggap sebagai gerakan saling-silang. Maksudnya, adalah serangkaian gerakan yang saling mendahului (overlapping). Pergerakan tangan dan kaki ketika berjalan bisa termasuk didalamnya.

9. Straight Ahead Action and Pose to Pose

Dari sisi resource dan pengerjaan, ada dua cara yang bisa dilakukan untuk membuat animasi. Yang pertama adalah Straight Ahead Action, yaitu membuat animasi dengan cara seorang animator menggambar satu per satu, frame by frame, dari awal sampai selesai seorang diri.

Yang kedua adalah Pose to Pose, yaitu pembuatan animasi oleh seorang animator dengan cara menggambar hanya pada keyframekeyframe tertentu saja, selanjutnya in-between atau interval antar keyframe digambar/dilanjutkan oleh asisten/animator lain.

\section{Stagging}

Seperti halnya yang dikenal dalam film atau teater, stagging dalam animasi juga meliputi bagaimana 'lingkungan' dibuat untuk mendukung suasana atau 'mood' yang ingin dicapai dalam sebagian atau keseluruhan scene.

\section{Appeal}

Appeal berkaitan dengan keseluruhan look atau gaya visual dalam animasi. Sebagaimana gambar yang telah menelurkan banyak gaya, animasi (dan beranimasi) juga memiliki gaya yang sangat beragam.

\section{Exaggeration}

Exaggeration adalah upaya untuk mendramatisir sebuah animasi dalam bentuk rekayasa gambar yang bersifat hiperbolis. Dibuat untuk 
menampilkan ekstrimitas ekspresi tertentu, dan lazimnya dibuat secara komedik. Banyak dijumpai di filmfilm animasi sejenis Tom \& Jerry, Donald Duck, Doraemon dan sebagainya.

Dari keduabelas prinsip animasi tersebut, prinsip yang paling dititikberatkan dalam film animasi Moriendo adalah stagging dan appeal (berkaitan dengan keseluruhan look atau gaya visual dalam animasi).

\section{Teori psikologi}

Proses menua (lansia) adalah proses alami yang disertai adanya penurunan kondisi fisik, psikologis maupun sosial yang saling berinteraksi satu sama lain. Keadaan itu cenderung berpotensi menimbulkan masalah kesehatan secara umum maupun kesehatan jiwa secara khusus pada lansia. Dilihat dari film Moriendo ini, dalam pembuatannya pencipta menggunakan teori psikologi untuk lansia untuk mendalami emosi karakter, dimana teori psikologi yang disoroti adalah Tipe Kepribadian Tergantung (Dependent personalitiy) dimana lansia tersebut pada tipe ini biasanya sangat dipengaruhi kehidupan keluarga, apabila kehidupan keluarga selalu harmonis maka pada masa lansia tidak bergejolak, tetapi jika pasangan hidup meninggal maka pasangan yang ditinggalkan akan menjadi merana, apalagi jika tidak segera bangkit dari kedukaannya.

\section{Teori storyline}

Struktur cerita berangkat dari storyline yang ada, kemudian cerita tersebut dibuat berdasarkan struktur. Bentuk-bentuk struktur yaitu;

\section{Struktur Paralel}

Struktur paralel memperbolehkan beberapa kejadian yang sedang berlangsung dalam satu waktu. Struktur paralel umumnya digunakan untuk satu aksi dari dua atau lebih karakter yang diperlukan dalam waktu yang bersamaan.

\section{Struktur Halte Bus}

Struktur ini merupakan variasi dari linier. Pada awalnya menceritakan kejadian secara lurus, namun tibatiba ketika suatu hal dibutuhkan terjadi, ia akan terjadi ditengahtengah cerita.

\section{Struktur Zig-zag}

Biasa ada pada opera sabun, struktur ini memperlihatkan bagaimana karakter keluar masuk dalam suatu sitkom. Karakter lama keluar, masuklah karakter baru.

\section{Struktur Lingkaran}

Struktur lingkaran adalah ketika sebuah cerita berakhir lebih kurang seperti pada saat cerita dimulai.

\section{Struktur Bintang}

Struktur ini yaitu struktur yang rumit dan kompleks. Karakter utamanya keluar masuk kedalam berbagai situasi yang mengelilinginya.

\section{Struktur Outline}

Struktur dasar dari sebuah cerita dapat diatur dalam beberapa kalimat. Rangkuman inilah yang dimaksudkan dengan outline cerita, dan kemudian divariasikan menjadi alur cerita yang baru.

\section{Struktur Template}

Struktur ini biasanya menggunakan struktur yang sudah ada sebagai titik awal cerita dan sedikit demi sedikit berubah membentuk cerita yang baru.

Film Moriendo menggunakan struktur lingkaran (sebuah cerita berakhir kurang lebih seperti pada saat cerita dimulai) dan struktur halte bus (pada awalnya menceritakan kejadian secara lurus, namun tiba-tiba ketika suatu hal dibutuhkan terjadi, ia akan terjadi ditengahtengah cerita).

\section{PEMBAHASAN}

Tujuan dari analisis ini adalah untuk mengangkat karya sastra yang memiliki cerita yang unik yang jarang ditemukan di Indonesia. Sebuah film animasi yang ditujukan untuk penonton yang lebih dewasa, karena sebagian besar animasi ditujukan kepada anak-anak. Cerita yang memberikan penyegaran terhadap dunia 
animasi dengan genre dan gaya visual yang tidak mainstream, menyebarkan pesan moral yang sublim, di mana setiap penonton dengan pengalaman hidup yang berbeda dapat mendapatkan pesan moral yang berbeda yang memancing dialog dalam diri kita sendiri.

\section{ANALISIS KONTEN}

\section{Logo Title}

\section{$M$ O R I E N D O}

Gambar 1 Logo Title Moriendo

Untuk desain title, film Moriendo ini menggunakan font Trajan yang memiliki cita rasa klasik dan elegan. Warna yang digunakan adalah hitam atau putih tergantung dari background yang digunakan dengan aksen gambar seekor burung gagak yang hinggap di atas huruf $\mathrm{O}$, yang merepresentasikan dewa kematian dalam animasi tersebut. Pada bagian atas title, ditambahkan judul asli dari cerita pendek yang diadaptasi, yaitu "Sebuah Pagi dan Seorang Lelaki Mati." Title tersebut didesain dengan sederhana, namun tetap terlihat elegan dan terkesan epic.

\section{Style}

Dalam proses $3 D$ modelling, film Moriendo ini menggunakan model lowpoly untuk mendapatkan kesan lipatan kertas pada karakter dan environment. Untuk texturing, tekstur karakter terkesan handpainted untuk menambah sisi artistik dalam animasi. Penonjolan karakteristik karakter dengan bentuk-bentuk ekstrim di bagian tertentu dengan tekstur artistik dibalut dalam hasil render semi realistis. Lalu untuk adegan imajinasi karakter, style dibuat seperti look 2 dimensi dengan warna saturasi rendah dan satu warna yang menonjol. Untuk beberapa bentuk karakter dan elemen-elemen di dalamnya digunakan beberapa adaptasi dari simbol-simbol tertentu seperti burung gagak, peti mati, sangkar burung, dsb. Warna yang digunakan merupakan perpaduan warna kelam dan warna cerah sebagai penanda kehidupan dan kematian. Style environment menggunakan pendekatan style pada cat air untuk menambah sisi artistik. Pada environment detail diminimalisir untuk memberikan depth dan fokus pada karakter.

\section{Motion Style}

Motion style yang digunakan dalam animasi pendek ini sebagian besar adalah gerakan kamera yang perlahan. Dengan banyak pengambilan close up karena yang ingin ditonjolkan dari animasi ini adalah ekspresi tiap karakter. Untuk beberapa adegan seperti adegan imajinasi karakter gerakan kamera yang digunakan cenderung cepat seperti kamera pada film-film action.

\section{Environment}
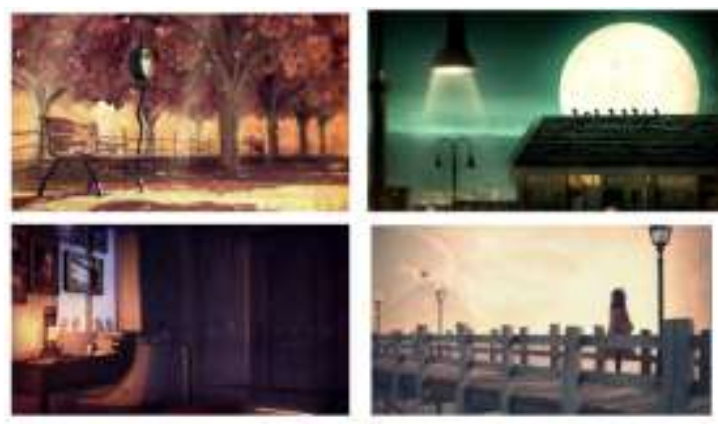

Gambar 2 Lingkungan Environment Moriendo

(Sumber: Data Internet, 2017)

Environment yang terdapat dalam film Moriendo adalah sebagai berikut:

\section{Taman kota}

Taman yang penuh dengan pepohonan tinggi dengan warna daun yang berubah-ubah sesuai musimnya. Terdapat sebuah jalan setapak utuk pejalan kaki. Tempat dimana terdapat jam besar dan kursi taman tempat dewa kematian dan wanita tua bertemu.

\section{Kursi taman}

Tempat dimana dewa kematian setiap kali mengistirahatkan dirinya di pagi hari setelah lelah memangsa roh-roh manusia. Bentuk peti mati yang sedang terbuka dianalogikan ke dalam bentuk kursi taman yang terdiri dari kayu-kayu tua. 


\section{Atap rumah}

Tempat dimana gagak akan hinggap di atap rumah sebagai penanda tempat tinggal orang yang akan dicabut nyawanya malam harinya. Atap-atap rumah digunakan untuk merepresentasikan kota kecil dengan menjejerkan atap-atap tersebut tanpa memperlihatkan apa yang ada di bawah atap tersebut.

\section{Rumah susun}

Tempat dimana wanita tua itu tinggal. Terlihat dari luar jendelajendela yang tersusun dan tembok yang retak dengan cat yang pudar untuk memberikan kesan kumuh.

5. Kamar tempat wanita tua tinggal Kamar rumah susun yang kecil dan penuh dengan barang. Perabotan terlihat tua dan jarang dibersihkan. Terdapat sebuah ranjang dan sebuah meja tua. Banyak menggunakan tekstur grunge untuk menambah efek kumuh.

\section{Karakter}
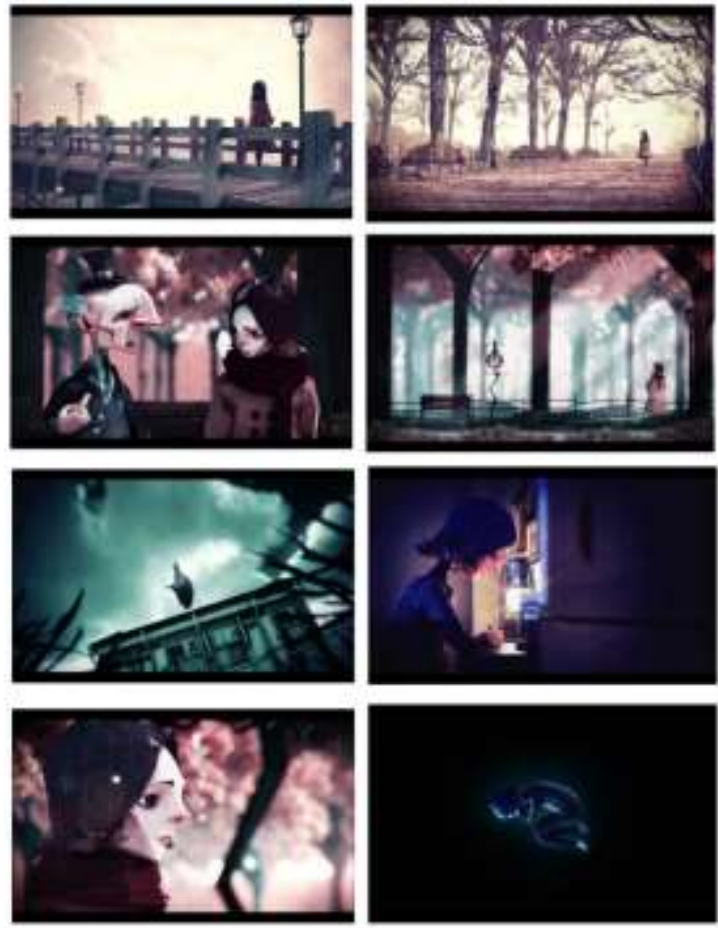

Gambar 3 Screenshot film animasi Moriendo

(Sumber: Data Internet, 2017)
Karakter dalam animasi pendek Moriendo terdiri dari 4 karakter. Masingmasing karakter memiliki penampilan dan ciri khas sendiri;

\section{Sang Kematian}

Kakek yang memiliki pribadi misterius. Dia merupakan dewa kematian yang dapat bertransformasi menjadi gagak. Berpakaian tuxedo berwarna hitam seperti pakaian berkabung dalam budaya barat dan memegang mawar berwarna hitam di tangannya.

\section{Wanita Tua}

Wanita yang terlihat frustasi dengan hidupnya hingga tidak memiliki hidup dalam kehidupannya sendiri. Rambut agak kurang terurus dan memakai pakaian yang cenderung tertutup dengan jaket-jaket panjang.

3. Gagak

Merupakan salah satu hewan yang merupakan simbolisasi dari kematian. Merupakan wujud dewa kematian di siang hari untuk menentukan mangsa yang akan dia cabut nyawanya di malam hari. Digambarkan seperti gagak pada umumnya.

\section{Kekasih Wanita Tua}

Kekasih dari wanita tua yang tidak diketahui keberadaannya dan telah meninggalkan wanita tua berpuluhpuluh tahun lalu. Kekasih wanita tua ini hanya tampak dalam sebuah foto tua yang disimpan oleh wanita tua.

\section{SIMPULAN}

Dengan majunya teknologi, animasi kini menjadi salah satu media komunikasi kreatif. Kombinasi dari cerpen alternatif sebagai basis skrip animasi dan animasi 3D dapat menghasilkan karya yang segar bagi publik Indonesia, tidak hanya baik secara visual, namun juga baik secara cerita. Melalui animasi yang mengadaptasi karya sastra, diharapkan karya sastra yang merupakan cerita aslinya pun dapat mulai dikenal masyarakat. Dalam membuat animasi, yang terpenting adalah perencanaan waktu atau timeline. Dimana sebagai animator harus memiliki kebijakan dalam menentukan target yang akan diraih. 
Target yang ingin dicapai pun harus realistis, harus menentukan target berdasarkan kualitas berbanding dengan waktu. Banyak manfaat yang didapatkan dengan menonton film-film animasi maupun box office untuk menambah pengayaan mengenai sinematografi yang baik dimana harus ada kebijakan dalam mengambil shot. Di satu sisi shot harus jelas menceritakan apa yang ingin disampaikan kepada penonton, dan di sisi lain harus estetis tanpa melupakan kejelasan jalan cerita.

\section{DAFTAR PUSTAKA}

Davis, Graham. 2008. The Designer's Toolkit: 1000 Colors Thousands of Color Combinations. San Francisco: Chronicle Books.
Kenworthy, Christopher. 2009. Master Shots: Advanced Camera Techniques to Get an Expensive Look On.Your Low Budget Movie. California: Michael Wiese Production.

Kusumawardhani, Noviana. 2011. Lelaki yang Membelah Bulan. Jakarta: KPG.

McCloud, Scott. 2007. Membuat Komik: Rahasia Bercerita dalam Komik, Manga dan Novel Grafis. Jakarta: Gramedia Pustaka Utama.

Mignola, Mike. 2009. Hellboy. Jakarta: Gramedia.

White, Tony. 2009. How to Make An Animated FIlms. Burlington: Focal Press. 